\title{
Keterampilan Metakognitif Siswa Kelas V dalam Pembelajaran Jarak Jauh di SD Negeri 02 Badak
}

\author{
${\text { Rosmadhani Maya Larasati }{ }^{1} \text {, } \text { Agung Nugroho }^{2} \& \text { Sri Harmianto }}^{3}$
}

Program Studi PGSD, Universitas Muhammadiyah Purwokerto, Indonesia

${ }^{凶}$ E-mail: mayalarasati5@gmail.com

\begin{abstract}
Abstrak
Tujuan penelitian ini yaitu untuk mengetahui keterampilan metakognitif siswa kelas 5 dalam proses pembelajaran jarak jauh di SD Negeri 02 Badak. Jenis penelitian adalah deskriptif kualitatif. Partisipan dalam penelitian yaitu guru, wali siswa, dan siswa kelas 5 dengan metode pengumpulan data yang dilakukan yaitu observasi, wawancara, dan dokumentasi. Uji keabsahan data yang digunakan yaitu triangulasi teknik dan sumber. Hasil penelitian ini menunjukkan bahwa proses pembelajaran yang dilakukan oleh guru dalam pembelajaran jarak jauh dalam rangka membentuk keterampilan metakognitif siswa dengan guru memberikan teknik pembelajaran kepada siswa untuk membentuk keterampilan metakognitif siswa, mempersiapkan materi yang akan dijelaskan kepada siswa, pengalaman belajar yang bermakna, serta memberikan proses pembelajaran jarak jauh yang menarik untuk membentuk keterampilan metakognitif siswa. Keterampilan metakognitif siswa, guru harus bisa menggunakan beberapa indikator yang menjadi faktor penunjang untuk membentuk keterampilan metakognitif siswa seperti mengidentifikasi tugas yang sedang dikerjakan, mengawasi kemajuan pekerjaan tugas siswa, mengevaluasi kemajuan pekerjaan siswa, serta memprediksi hasil yang akan diperoleh siswa. Keterampilan metakognitif siswa kelas 5 di SD Negeri 02 Badak mempunyai 3 kategori yaitu siswa yang mempunyai keterampilan metakognitif baik, siswa yang mempunyai keterampilan metakognitif sedang, dan siswa yang mempunyai keterampilan metakognitif rendah.
\end{abstract}

Kata Kunci: Keterampilan Metakognitif; Proses Pembelajaran Jarak Jauh.

\begin{abstract}
The purpose of this study was to determine the metacognitive skills of 5th grade students in the distance learning process at Badak 02 Elementary School. This type of research is descriptive qualitative. Participants in the study were teachers, guardians of students, and grade 5 students with the data collection methods conducted namely observation, interviews, and documentation. The validity test of the data used is the triangulation of techniques and sources. The results of this study indicate that the learning process undertaken by the teacher in distance learning in order to form students 'metacognitive skills with the teacher providing learning techniques to students to form students' metacognitive skills, preparing material to be explained to students, meaningful learning experiences, and providing processes interesting distance learning to shape students' metacognitive skills. Students 'metacognitive skills, the teacher must be able to use several indicators that are supporting factors to form students' metacognitive skills such as identifying the assignment that is being done, monitoring the progress of student work, evaluating the progress of student work, and predicting the results that students will get. The metacognitive skills of 5th grade students at SD Negeri 2 Badak have 3 categories: students who have good metacognitive skills, students who have moderate metacognitive skills, and students who have low metacognitive skills.
\end{abstract}

Keywords: Metacognitive Skills; Distance Learning Process. 


\section{PENDAHULUAN}

Pendidikan merupakan suatu usaha yang dilakukan secara terencana, sistematis dan logis dalam rangka membina manusia menuju proses pendewasaan sesuai dengan kebutuhan dan tuntutan hidup di lingkungannya. Melalui pendidikan juga diharapkan suatu negara mampu untuk menghadapi tuntutan kemajuan zaman yang sekarang ini semakin berkembang cepat. Undang-undang Nomor 20 Tahun 2003 tentang Sistem Pendidikan Nasional Pasal 1 ayat 1 bahwa : "Pendidikan adalah usaha sadar dan terencana untuk mewujudkan suasana belajar dan proses pembelajaran agar peserta didik secara aktif mengembangkan potensi dirinya untuk memiliki kekuatan spiritual keagamaan, pengendalian diri, kepribadian, kecerdasan, akhlak mulia serta keterampilan yang diperlukan dirinya, masyarakat, bangsa dan negara".

Saat sekarang salah satu aspek yang penting dari pendidikan adalah gaya belajar siswa suatu keberhasilan mereka tergantung pada cara belajar siswa dengan baik. Pada masa sekarang dengan mewabahnya virus covid-19 siswa tidak bisa pergi ke sekolah untuk menuntut ilmu. Belajar untuk siswa tidak hanya bisa dilakukan di sekolah namun dapat dilakukan di rumah. Dengan adanya virus Covid-19, siswa dapat belajar di rumah dengan memanfaatkan kecanggihan internet. Model pembelajaran jarak jauh yang dilakukan di rumah dengan memanfaatkan internet dapat membantu siswa dalam belajar. Siswa tidak bertatap muka langsung dengan guru yang mengajarnya, tetapi dengan model pembelajaran jarak jauh yang dilengkapi dengan kecanggihan internet masa kini akan memungkinkan terjadinya interaksi antara siswa dan guru dengan proses pembelajaran yang lebih efektif dan efisien.

Proses pembelajaran yang dilaksanakan sebelum adanya pandemi covid 19, guru menggunakan proses pembelajaran konvensional yang dilakukan di sekolah secara langsung. Setelah adanya covid 19, pemerintah memberikan pengarahan untuk pembelajaran dilakukan di rumah. Guru merubah proses pembelajaran konvensional menjadi proses pembelajaran jarak jauh. Usaha guru melakukan proses pembelajaran jarak jauh dengan memanfaatkan teknologi internet untuk melakukan pembelajaran jarak jauh dengan siswa. Proses pembelajaran yang dilakukan oleh guru dilakukan dengan membuat inovasi yang menarik agar siswa tidak mudah bosan dalam mengikuti proses pembelajaran jarak jauh di rumah. Adapun proses pembelajaran jarak mempunyai kelebihan dan kekurangan yang akan dihadapi oleh siswa. Kelebihan dalam pelaksanaan proses pembelajaran jarak jauh yaitu guru dan siswa dapat berkomunikasi secara mudah dengan menggunakan teknologi internet, siswa belum memahami materi dapat mengakses materi melalui internet secara mudah, dan merubah sikap siswa dari yang biasanya pasif menjadi lebih aktif. Sedangkan kekurangan dari pelaksanaan proses pembelajaran jarak jauh yaitu kurangnya interaksi antara guru dan siswa secara langsung, proses pembelajarannya cenderung ke arah pelatihan daripada pendidikan, dan menurunnya motivasi belajar siswa.

Berdasarkan hasil wawancara antara peneliti dengan guru kelas 5 SD Negeri 02 Badak terdapat beberapa permasalahan lain yaitu rendahnya prestasi siswa, kurangnya motivasi siswa untuk belajar, sikap kerja sama yang kurang, rendahnya sikap disiplin siswa, dan rendahnya keterampilan metakognitif siswa terhadap pembelajaran jarak jauh di rumah. Peneliti akan memfokuskan penelitian terhadap keterampilan metakognitif terhadap pembelajaran jarak jauh. Hal tersebut 
dikarenakan siswa belum bisa memecahkan permasalahan yang diberikan oleh guru, siswa sulit untuk mengontrol pemikirannya sendiri. Permasalahan yang dialami oleh siswa yaitu dengan siswa kurang dalam mencari sumber jawaban dari pertanyaan yang diberikan oleh guru. Siswa cenderung langsung mengerjakan soal untuk mencari jawaban tanpa mencoba melakukan kegiatan memahami soal, merencanakan penyelesaian, menyelesaikan masalah sesuai rencana dan melakukan pengecekan kembali terhadap semua langkah yang telah dikerjakan.

Berdasarkan kendala-kendala yang dihadapi oleh guru dalam melakukan proses pembelajaran jarak jauh yang membawa dampak rendahnya keterampilan metakognitif siswa, maka peneliti menitik beratkan bahwa permasalahan mengenai rendahnya keterampilan metakognitif siswa terhadap pembelajaran jarak jauh dijadikan acuan untuk diteliti. Penelitian ini juga diperkuat dengan penelitian sebelumnya yang meneliti mengenai rendahnya keterampilan metakognitif siswa yang dilakukan oleh Sri A. Widodo (2013: 108) indikator kesalahan saat membuat rencana pemecahan masalah yaitu siswa tidak mengetahui kecukupan dan kerpeluan syarat dari suatu masalah dan tidak menggunakan semua informasi yang telah dikumpulkan dari permasalahan.

\section{METODE PENELITIAN}

Jenis penelitian pada penelitian ini yaitu Penelitian Kualitatif. Menurut Creswell (2013: 4) penelitian kualitatif merupakan metode-metode untuk mengeksplorasi dan memahami makna yang oleh sejumlah individu atau sekelompok orang dianggap berasal dari masalah social atau kemanusiaan. Penelitian ini dilakukan di kelas 5 SDN 02 Badak terletak di Jl. Tambi Km.02 Simadu, Kecamatan Belik Kabupaten
Pemalang. Partisipan penelitian yaitu guru kelas 5, Wali siswa 3 orang, dan Siswa Kelas 5 mengambil 3 siswa. Teknik pengumpulan data yang digunakan peneliti yaitu menurut Creswell (2013: 267) membagi menjadi 3 diantaranya observasi, wawancara, dan dokumentasi. Teknik analisis data menurut Sugiyono (2015: 245) membagi menjadi 3 alur kegiatan yaitu reduksi data, penyajian data, dan penarikan kesimpulan. Uji keabsahan data yang peneliti gunakan menurut Creswell (2013:286) yaitu triangulasi sumber meliputi teknik wawancara kepada partisipan penelitian yaitu guru, wali siswa, dan siswa, dan triangulasi teknik meliputi melakukan wawancara dan dokumentasi kepada guru, wali siswa, dan siswa.

\section{HASIL DAN PEMBAHASAN}

Bagian ini membahas hasil penelitian dan pembahasan pada penelitian yang telah dilaksanakan oleh peneliti. Proses pengumpulan data dimulai dengan melakukan wawancara kepada informan dan dokumentasi. Bab ini akan membahas keterampilan metakognitif siswa kelas 5 dalam pembelajaran jarak jauh di SD Negeri 02 Badak.

\section{Proses Pembelajaran yang dilakukan oleh Guru dalam Pembelajaran Jarak Jauh}

Proses pembelajaran yang saat ini dilakukan oleh guru pada masa pandemi covid 19 menggunakan pembelajaran jarak jauh. Guru dituntut untuk bisa melakukan pembelajaran melalui pembelajaran jarak jauh. Proses pembelajaran yang dilakukan oleh guru dalam pembelajaran jarak jauh yang membentuk keterampilan metakognitif siswa sudah dilaksanakan dengan baik oleh guru kelas 5 di SD Negeri 02 Badak. Guru kelas 5 dan wali siswa menjelaskan bahwa saat guru melakukan proses pembelajaran dalam rangka membentuk keterampilan 
metakognitif siswa melalui pembelajaran jarak jauh, guru memberikan teknik pembelajaran yang dapat membentuk keterampilan metakognitif siswa. Proses pembelajaran yang dilakukan dengan cara pembelajaran jarak jauh dilakukan dengan baik oleh guru untuk membentuk keterampilan metakognitif siswa dengan guru mempersiapkan materi yang akan diberikan kepada siswa. Guru dapat memastikan siswa mendapatkan pengalaman belajar yang bermakna meskipun dilakukan melalui pembelajaran jarak jarak sehingga dapat membentuk keterampilan metakognitif siswa. Adapun proses pembelajaran yang dilakukan oleh guru dalam rangka membentuk keterampilan metakognitif siswa dalam pembelajaran jarak jauh, antara lain;

\section{Teknik pembelajaran yang dilakukan oleh guru dalam proses pembelajaran jarak jauh,}

Guru kelas 5 mengatakan bahwa teknik pembelajaran yang digunakan dalam proses pembelajaran jarak jauh dalam membentuk keterampilan metakognitif siswa menggunakan teknik pemecahan masalah. Guru memberikan kebebasan kepada siswa untuk menjawab pertanyaan tugas yang diberikan, maka siswa akan mencari sendiri untuk menjawab pertanyaan tersebut. Siswa akan mengolah pemikirannya sendiri dan mengontrol pemecahan masalah yang ada pada tugas tersebut. Adanya teknik pemecahan masalah sendiri menjadikan siswa dapat mengetahui kesadaran kognisinya.

Wali siswa menjelaskan bahwa guru dalam memberikan teknik pembelajaran kepada siswa menggunakan teknik pemecahan masalah. Tugas yang diberikan oleh guru, salah satu pertanyaan yang harus dijawab meminta siswa untuk memecahkan suatu permasalahan. Hal tersebut dapat melatih siswa untuk merencanakan sebuah jawaban atau solusi untuk memecahkan permasalahan tersebut. Dalam teknik pemecahan masalah, siswa bebas mencari informasi untuk memecahkan masalah atau menyelesaikan tugas. Teknik pemecahan masalah yang diberikan oleh guru meminta siswa untuk mencari sumber jawaban sendiri dengan mengunakan pemikiran sendiri atau dengan siswa mencari sumber dibuku bacaan yang dimiliki oleh siswa. Pernyataan tersebut juga sama dengan yang disebutkan oleh Kirkly dalam Anggo, (2011: 28) "Bahwa pemecahan masalah merupakan perwujudan dari suatu aktivitas mental yang terdiri dari bermacam-macam keterampilan dan tindakan kognitif'. Artinya pemecahan masalah marupakan kegiatan yang memerlukan keterampilan dan pengetahuan. Gambar soal dan jawaban siswa menggunakan teknik pemecahan masalah sebagai berikut:

\section{Persiapan Materi yang dilakukan oleh Guru}

Persiapan materi yang dilakukan oleh guru pada proses pembelajaran jarak jauh tentunya berbeda dengan mempersiapkan materi ketika bertatapan secara langsung dengan siswa. Dalam proses pembelajaran jarak jauh untuk membentuk keterampilan metakognitif siswa, guru menyiapkan materi dengan memanfaatkan gadget untuk dapat menyampaikan materi kepada siswa. Guru dengan siswa tidak dapat bertatap muka secara langsung untuk melakukan proses pembelajaran, jadi untuk mempermudah guru dalam mempersiapkan materi memanfaatkan penggunaan gadget untuk melakukan pembelajaran dengan siswa.

Siswa menjelaskan bahwa merasa nyaman dan senang dengan cara guru yang memberikan materi melalui whatsapp, hal tersebut dapat memudahkan siswa untuk menerima materinya. Dalam memberikan materi guru menjelaskan dengan baik dan pemberian tugas juga dijelaskan kepada 
siswa. Pemberian tugas yang diberikan kepada siswa, guru memberikan target 1 minggu untuk mengumpulkan tugas tersebut. Pengumpulan tugas masih menggunakan whatsapp sebagai alternatif untuk menggumpulkan tugas yang sudah diberikan oleh guru. Siswa diminta untuk memahami materi yang diberikan oleh guru, siswa diberikan tugas untuk mencatat materi dan menjawab soal latihan dengan membaca bacaan yang ada dibuku tema. pernyataan yang dikatakan oleh E. Mulyasa (2013) bahwa guru yang profesional harus mampu mengembangkan persiapan mengajar yang baik, logis dan sistematis.

Guru mempermudah memberikan materi kepada siswa melalui whatsapp, dengan guru memotret materi yang akan disampaikan kemudian dibagikan kepada siswa. Materi yang sudah dibagikan kepada siswa, akan disimak dengan baik oleh siswa agar dapat memahami materinya. Guru dalam menjelaskan materi membagikan video pembelajaran berupa penjelasan materi yang akan siswa simak dan pahami. Siswa akan mudah memahami dengan guru menjelaskan materi secara runtut dan benar. Materi yang sudah jelaskan, maka akan dicatat oleh siswa kemudian siswa diberikan tugas untuk dikerjakan.

\section{Pengalaman belajar yang bermakna}

Siswa belajar di rumah akan banyak mengalami hal-hal tertenu yang berkaitan dengan pembelajaran yang diberikan oleh guru melalui pembelajaran jarak jauh. Dengan siswa mengalami langsung, maka siswa akan dapat lebih memahami mengenai pembelajaran yang diberikan oleh guru. Pengalaman langsung yang mempunyai makna bagi siswa dapat mengolah pola pikir kognitif siswa untuk mengikuti pembelajaran dengan baik. Siswa menjelaskan bahwa guru dalam memberikan pembelajaran kepada siswa sudah memberikan pengalaman yang bermakna bagi siswa. Dengan menghubungkan materi pembelajaran dengan hal-hal yang ada di sekitar siswa ketika berada di rumah, kemudian akan menjadikan siswa mampu mengolah sendiri materi yang sudah diterimanya. .

Siswa mengalami suatu peristiwa secara langsung tentunya hal tersebut akan menjadi pengalaman yang bermakna bagi siswa. Dalam proses pembelajaran jarak jauh yang akan membentuk keterampilan metakognitif siswa melalui pemberian pembelajaran bermakna, maka siswa akan mampu mengolah sendiri kesadaran kognitifnya. Siswa dapat mengolah kesadaran kognitifnya, dikarenakan guru dalam memberikan tugas kepada siswa berkaitan dengan lingkungan sekitar siswa. Tugas yang berkaitan dengan lingkungan sekitar siswa akan memberikan proses belajar yang bermakna, karena siswa dapat merasakan langsung perisitwa yang terjadi disekitarnya. Menurut Muchlas Samani (2017) mengemukakan bahwa apapun metode pembelajarannya, maka harus bermakna (meaningfull learning). Pembelajaran bermakna merupakan suatu proses mengaitkan informasi baru pada konsepkonsep relevan yang terdapat dalam struktur kognitif seseorang.

\section{Proses pembelajaran guru dalam proses pembelajaran jarak jauh}

Guru kelas V menjelaskan bahwa dalam melakukan proses pembelajaran jarak jauh dilakukan secara interaktif agar siswa dapat memahami materi yang akan dijelaskan. Siswa akan lebih aktif dalam pengembangan keterampilan berpikirnya, karena kesempatan yang lebih luas dalam mengumpulkan informasi. Guru memberikan penjelasan terlebih dahulu mengenai materi yang akan dipelajari oleh siswa dengan cara guru menjelaskan materi dengan meminta siswa untuk membuka halaman materi yang ada 
pada buku tema untuk dipahami oleh siswa, kemudian siswa bisa mendengarkan materi yang sudah dijelaskan oleh guru. Guru menjelaskan materi, kemudian guru menjelaskan mengenai tugas yang harus dikerjakan oleh siswa. Pernyataan yang diungkapkan oleh Nur Khasanah (2012) bahwa pembelajaran jarak jauh dirumuskan sebagai pembelajaran dengan menggunakan suatu media yang memungkinkan terjadi interaksi antara pengajar dan pembelajar.

Siswa menjelaskan bahwa guru dalam menjelaskan materi selama proses pembelajaran jarak jauh dilakukan secara runtut dan benar. Kegiatan pembelajaran untuk membentuk keterampilan metakognitif siswa dalam pembelajaran jarak jauh, guru memanfaatkan teknologi informasi seperti gadget sebagai media dalam menyampaikan tugas kepada siswa. Guru menjelaskan langkah-langkah penyelesaian yang harus dilakukan siswa untuk mengerjakan tugas. Guru menjelaskan siswa diberikan tugas. Tugas yang diberikan oleh guru berupa tugas yang bersifat konkret atau nyata, hal tersebut agar siswa dapat terlibat secara langsung dalam kejadian yang terjadi disekitar lingkungan rumah.

\section{Keterampilan Metakognitif Siswa dalam Pembelajaran Jarak Jauh}

Pemahaman

guru

mengenai

keterampilan metakognitif sebelum peneliti melakukan penelitian, guru belum memahami tentang keterampilan metakognitif. Peneliti sebelum melakukan kegiatan pengambilan data dengan cara wawancara, peneliti menjelaskan terlebih dahulu pengertian mengenai keterampilan metakognitif. Peneliti menjelaskan tentang keterampilan metakognitif, supaya guru dapat memahami keterampilan metakognitif secara rinci dan memberikan pemahaman baru mengenai keterampilan metakognitif kepada guru. Sejalan dengan pernyataan yang diberika oleh Kaune dalam (Arum, 2017:25) menyimpulkan bahwa "keterampilan metakognitif merupakan kemampuan yang melihat kembali proses berpikir yang dilakukan seseorang, metakognitif terdiri dari tiga elemen planning, monitoring, dan reflection". Guru menjadi memahami keterampilan metakognitif, setelah peneliti menjelaskannya dengan memberikan contoh nyata mengenai keterampilan metakognitif siswa. Adapun keterampilan metakognitif siswa dalam pembelajaran jarak jauh antara lain:

\section{Mengidentifikasi Jenis Tugas yang dikerjakan Siswa,}

Guru memberikan penjelasan pengantar mengenai tugas yang mereka kerjakan yang hanya bersifat instruktif bukan menjelaskan arahan jawaban-jawaban yang harus disusun oleh siswa. Guru memberikan kebebasan pada siswa untuk berpikir dan memahami jenis tugas, tingkat kesulitan tugas dan langkah penyelesaian yang harus ditempuh. Wali siswa menjelaskan bahwa guru memberikan penjelasan mengenai tugas yang akan dikerjakan oleh siswa. Guru menjelaskan langkah-langkah penyelesaian tugasnya, dengan memberikan penjelasan ulang mengenai materi yang menjadi pertanyaan tugas yang akan dikerjakan oleh siswa.

Siswa akan menjadi paham untuk menjawab pertanyaannya, kemudian sebagai wali siswa mengajarkan kembali langkahlangkah yang sudah dijelaskan oleh guru. Dengan penjelasan langkah-langkah penyelesaian tugas tersebut, maka siswa akan mampu mengerjakan tugasnya dengan pemikiran sendiri. Siswa menjelaskan bahwa dalam memahami jenis tugas, siswa lebih banyak membaca buku bacaan di buku tema. Dengan siswa menggunakan pemikian 
sendiri dalam mengerjakan tugas maka menunjukkan bahwa metakognitif siswa sudah baik. Pernyataan dari Muhammad Satriawan (2018) bahwa siswa diarahkan untuk melibatkan pengetahuan yang sudah diperolehnya dahulu untuk digabungkan dengan informasi yang diperoleh dari teks yang dibaca untuk kemudian digunakan dalam mengimajinasikan kemungkinan yang akan terjadi berdasar atas gabungan informasi yang sudah dimilikinya.

\section{Mengawasi kemajuan Pekerjaan}

Guru mengarahkan siswa untuk selalu mengawasi kemajuan pekerjaanya. Siswa harus dengan sistematis memeriksa penyelesaian tugas dan kualitas tugas yang siswa kerjakan. Dalam mengerjakan tugas siswa diawasi melalui pembelajaran jarak jauh oleh guru, siswa diminta untuk mengerjakan tugasnya sendiri dan menggunakan langkah-langkah yang sudah dijelaskan oleh guru. Dalam menilai kemajuan siswa guru dapat melihat dari pengerjaan siswa dengan jawaban yang dijawab menggunakan pemikiran sendiri. Kemandirian siswa juga dilihat oleh guru melalui kejujuran dalam mengerjakan tugas, kemudian guru membandingkan jawaban dari masing-masing siswa.

Wali siswa menyatakan bahwa siswa dalam mengerjakan tugas diawasi oleh orang tua, dan orang tua ikut serta dalam pengecekan hasil jawaban siswa. Pengawasan dari orang tua perlu dilakukan agar siswa dapat mengerjakan tugas dengan teliti. Siswa dibimbing oleh orang tua, karena pada pembelajaran jarak jauh yang dilakukan di rumah. Siswa dalam mengerjakan tugas diawasi oleh orang tua, dan diberikan arahan langkah-langkah dalam mengerjakan tugas yang diberikan oleh guru. Pernyataan dari Kuntjojo (2018) bahwa mengawasi kemajuan pekerjaan tugas siswa merupakan keterampilan yang mengutamakan proses sistematis berfikir dalam pemecahan masalah.

\section{Mengevaluasi kemajuan pekerjaan siswa}

Guru berperan untuk memberikan penjelasan mengenai proses evaluasi yang bisa diterapkan oleh siswa. Proses evaluasi sangat penting fungsinya agar siswa bisa mendapatkan nilai serta pelajaran dari pengalaman kegiatan atau tugas yang baru siswa kerjakan. Dalam pembelajaran jarak jauh untuk membentuk keterampilan metakognitif siswa, guru memberikan evaluasi mengenai tugas yang dikerjakan oleh siswa secara berkala agar siswa dapat memahami tugas yang sudah dikerjakan. Pernyataan dari Anatahime (2018) bahwa keterampilan pemantauan sebagai kesadaran (awareness) tentang apa yang ingin diketahui. Pemantauan akan memberikan informasi tentang status dan kecenderungan bahwa evaluasi yang diselesaikan berulang dari waktu ke waktu.

Wali siswa menjelaskan bahwa guru memberikan evaluasi setiap siswa selesai mengerjakan tugas. Wali siswa memberikan evaluasi terhadap jawaban siswa, agar jawaban siswa dapat sesuai dengan pertanyaan yang diberikan oleh guru. Siswa diberikan pengarahan untuk dapat mengerjakan tugas secara runtut, agar dapat meminimalisir kesalahan jawaban. Siswa menjelaskan bahwa guru dan orangtua memberikan pengarahan mengenai penyelesaian tugas yang diberikan. Pemberian pemahaman kepada siswa akan dapat memberikan dampak bagi siswa untuk bisa menerapkan pemahamannya sesuai dengan cara berpikir atau kognitifnya.

\section{Memprediksi Hasil Pekerjaan siswa}

Siswa diarahkan untuk membuat gambaran kemungkinan yang akan terjadi atas informasi yang sudah siswa peroleh dengan pengetahuan baru yang akan diperoleh. Oleh karena itu penting guru 
untuk menganalisa pemahaman awal siswa sebelum pelajaran dimulai. Dalam pembelajaran jarak jauh untuk membentuk keterampilan metakognitif siswa, maka guru memberikan gambaran kepada siswa mengenai pemahaman materi yang akhirnya siswa akan diminta untuk menganalisa jawabannya sendiri.

Wali siswa menjelaskan bahwa siswa diberikan pengalaman secara nyata untuk bisa menganalisis jawabannya sendiri. Dengan siswa dapat menganalisis jawabannya sendiri, bentuknya dengan siswa dapat menyimpulkan jawaban yang benar untuk menjawab pertanyaan yang ada pada soal. Siswa menjelaskan bahwa guru dalam memberikan tugas bersifat konkret atau nyata, siswa diminta untuk bisa menganalisis jawabannya sendiri yang sesuai dengan pemikiran siswa. Hal tersebut akan membuat siswa menjadi lebih memahami materi yang sudah dijelaskan oleh guru. Sejalan dengan pernyataan yang diberikan oleh Ririn Apriyanti (2016) bahwa proses penilaian pencapaian tujuan dan pengungkapan masalah kinerja untuk memberikan umpan balik bagi peningkatan kualitas kinerja itu sendiri

Teknik pembelajaran jarak jauh yang dilakukan oleh guru dengan menggunakan teknik pemecahan masalah. Siswa bebas mencari informasi untuk memecahkan masalah atau menyelesaikan tugas. Siswa dapat menjawab pertanyaan yang ada pada tugas dengan menggunakan pemikiran sendiri, membaca buku, bertanya kepada orangtua dan sumber-sumber belajar lainnya. Guru memberikan kebebasan kepada siswa untuk menjawab pertanyaan tugas yang diberikan akan membuat siswa mampu mengolah pemikirannya sendiri dan mengontrol pemecahan masalah yang ada pada tugas tersebut. Teknik pemecahan masalah digunakan untuk menjadikan siswa dapat mengetahui kesadaran kognitifnya. Guru dalam mempersiapkan materi tentunya berbeda dengan persiapan materi pada saat melakukan proses pembelajaran di sekolah.

Guru dalam melaksanakan proses pembelajaran jarak jauh, untuk mempersiapkan materinya dengan memanfaatkan gadget untuk dapat menyampaikan materi kepada siswa. Guru dan siswa tidak dapat bertatap muka secara langsung, maka guru menggunakan gadget untuk memberikan materi dan membuat grup di aplikasi whatsapp untuk memudahkan siswa dalam menerima materi. Guru mengirimkan materi melalui whatsapp, kemudian siswa dapat menyimak materinya dengan mudah. Materi yang dikirimkan oleh guru akan diberikan penjelasan yang rinci agar siswa dapat memahami materinya. Guru dapat mengirimkan video, dengan isi video tersebut adalah rekaman guru pada saat memberikan penjelasan mengenai materi yang akan diberikan kepada siswa. Pengalaman belajar yang bermakna bagi siswa tidak hanya didapatkan di sekolah melainkan pada kondisi saat ini, siswa dapat menerima pengalaman belajar yang bermakna walaupun siswa hanya belajar di rumah.

Siswa belajar di rumah akan banyak mengalami hal-hal secara langsung yang nyata sesuai dengan materi yang telah diberikan oleh guru. Cara guru dalam memberikan pengalaman belajar yang bermakna bagi siswa walaupun di rumah, dengan guru memberikan tugas yang bersifat nyata kepada siswa agar siswa dapat merasakan secara langsung. Guru menyampaikan materi dengan memberikan video pembelajaran yang berkaitan dengan materi, kemudian siswa diminta untuk menyimak isi dari video mengenai kejadian yang ada di sekitar lingkungan rumah.

Proses pembelajaran jarak jauh yang 
dilakukan oleh guru, dilakukan secara interaktif agar siswa dapat dengan mudah menerima materi yang diberikan oleh guru. Siswa akan lebih aktif dalam pengembangan keterampilan berpikirnya, karena kesempatan yang lebih luas dalam mengumpulkan informasi. Guru memberikan penjelasan terlebih dahulu kepada siswa mengenai materi yang akan dibahas melalui whatsapp. Guru meminta siswa untuk dapat membuka materi yang sudah dijelaskan, kemudian siswa bisa memahami materinya dan guru memberikan tugas kepada siswa. Proses pembelajaran jarak jauh yang dilakukan dengan tertata dan efektif, maka akan menghasilkan pembelajaran yang akan membuat siswa merasa tidak bosan dalam mengikuti proses pembelajaran jarak jauh.

Keterampilan metakognitif siswa kelas 5 di SD Negeri 02 Badak dibagi menjadi 3 kategori yaitu dengan kategori siswa yang mempunyai metakognitif yang baik, sedang dan rendah. Siswa yang memiliki keterampilan metakognitif yang baik, maka siswa tersebut akan mampu memahami jenis tugas yang diberikan oleh guru dengan mengunakan pemahamannya sendiri tanpa bantuan dari orang tua. Siswa akan mampu menjawab tugas yang diberikan oleh guru menggunakan pemikirannya sendiri dan mudah untuk menganalisis jawabannya sendiri. Siswa yang memiliki keterampilan metakognitif yang sedang, maka siswa yakin dan benar dalam menjawab pertanyaan yang ada pada tugas. Siswa mampu menyelesaikan tugas dengan menggunakan langkah-langkah yang sudah dijelaskan oleh guru. Siswa yang memiliki keterampilan rendah, siswa memahami soal dengan benar tetapi siswa tidak menuliskan apa yang diketahui dan apa yang ditanyakan dalam soal padahal siswa bisa membaca maksud soal dengan baik. Siswa belum selesai dalam menjawab dan juga belum mendapatkan hasil sesuai dengan harapan.

\section{KESIMPULAN}

Proses pembelajaran yang dilakukan oleh guru dalam pembelajaran jarak jauh dalam rangka membentuk keterampilan metakognitif Siswa, Guru memberikan teknik pembelajaran pemecahan masalah. Siswa diberikan suatu permasalahan, kemudian siswa diminta untuk memecahkan permasalahan tersebut menggunakan pemikirannya sendiri. Pemberian materi yang dilakukan oleh guru menggunakan whatsapp, guru mengirimkan materinya kemudian siswa dapat menyimak dan memahami materi tersebut. Pemberian tugas yang diberikan oleh guru, diberikan kepada siswa melalui whatsapp. Materi yang dijelaskan oleh guru, biasanya guru membuat sebuah video pembelajaran yang berisi materi yang terkait. Pemberian pengalaman belajara yang bermakna bagi siswa, menjadikan penunjang bagi peningkatan proses pembelajaran jarak jauh. Siswa diberikan tugas yang bersifat nyata, dengan siswa melakukan pengamatan dan wawancara di lingkungan sekitar rumah. Proses pembelajaran jarak jauh yang dilakukan oleh guru, memudahkan siswa dalam menerima materi yang akan diterima oleh siswa karena guru menggunakan whatsapp untuk penyampaian materinya. Proses pembelajarannya, guru tidak hanya memberikan materi tetapi juga memberikan tugas. Siswa akan merasa senang dan tidak merasa bosan ketika proses pembelajaran jarak jauh yang dilakukan oleh guru dilaksanakan dengan menyenangkan. Keterampilan Metakognitif siswa dalam pembelajaran jarak jauh, Keterampilan metakognitif berkaitan dengan proses berpikir siswa tentang berpikirnya agar menemukan strategi yang tepat dalam memecahkan masalah. Setiap siswa memiliki kemampuan yang berbeda-beda dalam 
menghadapi masalah. Membentuk keterampilan metakognitif siswa, guru harus bisa menggunakan beberapa indikator yang menjadi faktor penunjang untuk membentuk keterampilan metakognitif siswa seperti mengidentifikasi tugas yang sedang dikerjakan, mengawasi kemajuan pekerjaan tugas siswa, mengevaluasi kemajuan pekerjaan siswa, serta memprediksi hasil yang akan diperoleh siswa.

\section{DAFTAR RUJUKAN}

Adi, Sri Widodo., (2013). "Analisis Kesalahan Pemecahan Masalah Divergen Tipe Membuktikan pada Mahasiswa Matematika", Jurnal Pendidikan dan Pengajaran, Vol. 2, pp, 106-11,

Anatahime. (2020). Keterampilan Metakognitif,http://biologyeducationresear ch.blogspot.com/2009/12/keterampilanmeta kognitif.html , diakses pada tanggal 3 Juni 2020.

Anggo, Mustamin., (2011). "Perlibatan Metakognisi dalam Pemecahan Masalah Matematika", Jurnal Edumatica, Vol. 01, No. 01, pp. 25-32, 2011.

Anggo, Mustamin. (2011). Pemecahan Masalah Matematika Kontekstual Meningkatkan Kemampuan Metakognisi siswa: Jurnal Edumatica. Volume 01 Nomor 02, Oktober 2011; 35-42.

Apriyanti, Ririn. (2016), "Analisis keterampilan metakognitif siswa dalam pemecehan masalah matematika aplikasi perbandingan". Jurnal Pendidikan dan pengajaran. Vol. 02, hal.6

Arum, Rahmi, Puspita. (2017). Deskripsi kemampuan Metakognisi siswa SMA egeri 1 Sokaraja dalam Menyelesaikan soal Cerita Matematika Ditinjau dari Kemandirian Belajar Siswa. Alpha Math Jurnal Pendidikan Matematika. Vol.3,No. 1; 23-33.

Gredler, M. E. (2011). learning and Instruction Teori dan Aplikasi. Jakarta Kencana.

Creswell, J. W, .(2013). Research Design pendekatan kualitatif, Kuantitatif, dan Micxed. Pustaka Belajar, Yogyakarta.

Khasanah, N, .(2012). "Evaluasi Pelaksanaan Program Rintisan PPJJ (Pengembangan Pendidikan Jarak Jauh) Iain Walisongo Menuju Pembelajaran Online (Kerjasama DBE 2 USAID dengan IAIN Walisongo Semarang)", Jurnal Phenomenon, Vol. 2, No. 1, pp. 32,

Kuntjojo. (2020). , Metakognisi dan Keberhasilan Belajar Peserta Didik, http://ebekunt.wordpress.com/2009/04/12/m etakognisi-dan-keberhasilan-belajarpesertadidik/, diakses pada tanggal 11 Mei 2020.

Muchlas, Samani (2017). Pendidikan Bermakna: Integrasi Life Skill-KBKCTLMBS; Surabaya: SIC

Mulyasa. (2013), Pengembangan dan Implementasi Kurikulum 2013, PT Remaja Rosdakarya, Bandung.

Satriawan, M. (2020)., Keterampilan Metakognitif, http://muhammadsatriawan27.blogspot.com/ 2013/09/metakognitif.html, diakses pada tanggal 8 Mei 2020

Sugiyono. (2015)., Metode Penelitian Pendidikan, Alfabeta, Bandung. 